\title{
The practice learning experiences of student teachers at a rural campus of a South African university
}

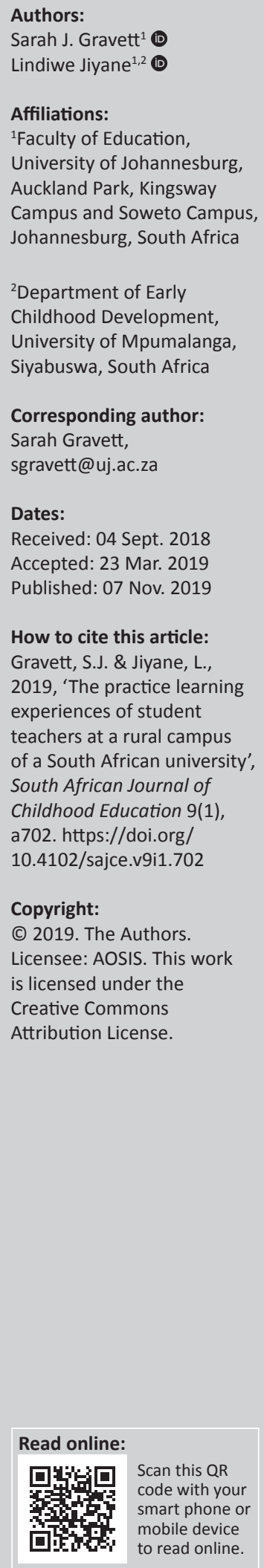

Background: There is considerable agreement that learning to teach is optimised when coursework learning is combined with quality practice learning experiences in schools.

Aim: The main aim of this study was to explore the views of a group of student teachers on their practice learning experiences in a 'teaching school' (TS) and in the other schools where they were placed for school experience.

Setting: The study was conducted at a rural campus of a South African university.

Methods: Quantitative (questionnaire) and qualitative (focus group) data were collected, involving all the student teachers in the programme $(n=100)$. The responses to the questionnaire were analysed descriptively, and the constant comparative method of data analysis was used to analyse the focus group interviews.

Results: The overall pattern in the data shows that the practice learning experiences contributed to the student teachers' development as teachers - not only at the TS but also at the schools where they were involved in work integrated learning, despite challenges, including teacher absenteeism and lack of guidance. Involvement in these schools potentially enables an understanding of the challenges that are typical in many South African schools. However, school experience in a well-functioning school remains crucial. Were it not for the TS, the majority of the student teachers would not have been exposed to mentoring and good teaching practices to be emulated.

Conclusion: The study concludes that TSs indeed hold the potential to strengthen the teaching practice component of teacher education considerably. International experience with school partnerships and the experience at another South African university also attest to this.

Keywords: School Experience; Practicum; Teaching Practice; Work Integrated Learning; Teaching School.

\section{Background and focus of the study}

This article gives an account of the views of a group of fourth-year student teachers on their practice learning ${ }^{1}$ experiences in schools while enrolled for the Bachelor of Education in Foundation Phase ${ }^{2}$ Teaching at a rural campus of a university in South Africa.

It is widely acknowledged that good teacher education programmes have an integrative design coursework learning and practice learning experiences in schools are mutually reinforcing (Darling-Hammond 2006). The practicum ${ }^{3}$ model, generally followed in South Africa, is the placing of student teachers in a variety of schools, in blocks, over the course of their 4 years of study, with the bulk of the school experience taking place during the fourth year. The expectation is that the school experience component, also referred to as Work Integrated Learning (WIL) in South Africa, should allow student teachers to experience the diversity of schooling in the country, although in functional schools, and that it should be formally supervised and assessed.

The model in the programme that we report on has an added dimension. In addition to the school experience in blocks, similar to other public teacher education institutions, ${ }^{4}$ the university

1.We use the term 'practice learning' to refer to student teachers' learning from and in practice at the 'teaching school' and the other schools where they are involved in school experience.

2.The term 'foundation phase' refers to the first 4 years of schooling in South Africa.

3.Many terms are used in the literature to refer to the time that student teachers spend in schools as part of their teacher education programmes, for example, practicum, teaching practice, student teaching, practice teaching, field experience and clinical experiences. In South Africa, the term 'work integrated learning' (WIL) is used to refer to learning in the workplace - classroom and school settings. It includes 'learning-from-practice' and 'learning-in-practice', taking place in classrooms and school settings. The term 'school It includes 'learning-from-practice' and 'learning-in-practice', taking place in classrooms and school settings
experience' is also widely used. We use both terms in the article when referring to the South African situation.

4.In South Africa, the far majority of teachers are educated at public higher education institutions, namely, universities or universities of technology. We use the term 'teacher education institution' in this article to refer to these institutions. 
collaborates with a public school located close to the university campus. This collaboration was initiated through an agreement with the school and the provincial department of education with a view to gradually establish the school as a 'Teaching School' (TS). Student teachers are involved in this school during all four years of the degree. Student teacher participation includes structured observation tasks, working as classroom assistants and doing limited teaching from their second year. Student teachers also participate in service learning, planning and implementing projects that will benefit the school. The teachers in the school are tasked to act as mentors to student teachers. The expectation is that they plan lessons with the student teachers and give guidance on the lesson preparation, assist with the development of teaching aids, assess student teachers when they teach, provide them with feedback on lesson presentation and guide them on classroom management.

The notion of a 'teaching school' emanates from the Strategic Planning Framework for Teacher Education and Development in South Africa 2011-2025 (Departments of Basic Education and Higher Education and Training [DBE \& DHET] 2011). This Framework proposes the strengthening of the teaching practice or school experience component of teacher education programmes through, inter alia, establishing professional practice schools and TSs. Teaching schools, as envisaged in the Framework, show some similarities to university training schools in Finland (Ramsaroop 2016). Teaching schools are conceptualised as 'teaching laboratories' located close to a teacher education delivery site, where student teachers can engage in 'learning-from-practice' (DBE \& DHET 2011:18). Learning from practice is explained in the Revised policy on the minimum requirements for teacher education qualifications as the study of practice using discursive resources to analyse practices to theorise practice (DHET 2015).

The gradual establishment of the TS commenced in 2013, starting with the upgrading of the infrastructure of the school. During that time the school was low-functional, ${ }^{6}$ not unlike many schools in South Africa, particularly in rural areas. Five years later, as a result of concerted development efforts, the school can be described as functional, although much still needs to be done to move it towards a highfunctional school, which will enable student teachers to consistently experience a model environment and good teaching practices to emulate (Gravett \& Ramsaroop 2017).

It is against this background that we report on a study that aimed to explore student teachers' views of their practice learning experiences in the TS and in other schools ${ }^{7}$ where they were placed for school experience. We wanted to delve into the proverbial 'black box' into which student teachers 5. Hereafter referred to as 'the Framework'.

6.We view a functional school as a well-run and well-managed school in which there is basic compliance in terms of teaching hours, curriculum coverage and good teaching practices. The school environment is clean and there is evidence of efforts to create an environment conducive for teaching and learning.

7.Also referred to as WIL schools in the rest of the article. disappear during the practicum (Burn, Childs \& McNicholl 2007) at schools. A secondary aim of the study was to investigate the validity of our perception that student teachers are of the view that their involvement in the TS substantially enhances practice learning. In addition, we were interested in obtaining insights into whether a TS indeed has the potential to considerably strengthen the teaching practice or school experience component of teacher education programmes through enabling meaningful WIL, as envisaged in the Framework (DBE \& DHET 2011).

The next section explores the literature that frames the study. Then the research methods are discussed, followed by a presentation of the data and discussion of the findings.

\section{School practicum as a fundamental component of initial teacher education}

There is considerable agreement that learning to teach is optimised when 'theoretical knowledge' is combined with 'coherent, systematic, authentic and comprehensive practicum experiences' (Abdal-Haqq 1997:6). A recent study on highperforming education systems (Darling-Hammond et al. 2017) notes that teacher preparation in these systems includes well-mentored clinical experience. All of the countries recognise that student teachers learn best about teaching when they are in actual classrooms coached and supported by expert mentor teachers who model the practices they need to learn. In addition, student teachers across a range of international contexts attest to the value of school-based practicum in preparing them for teaching. They often claim that they gained more from the practicum than from the other components of their teacher education programme (White \& Forgasz 2016).

Even though the practicum is clearly an indispensable component of pre-service teacher education, it is also contested. The teacher education literature abounds with questions and dilemmas related to the practicum (Bacevich et al. 2015; White \& Forgasz 2016). These include questions about the purpose(s) of the practicum, timing, duration and sequence of the practicum within the programme; what student teachers should be doing (and not doing); how much responsibility they should be assigned; what they will learn and how; the assessment of their learning and development; and the type of contexts (mainly schools) suitable for practicum.

The purported purposes of the practicum vary. The term 'practice teaching' implies that the practicum provides the space for student teachers to learn the practice of teaching. The practicum is also viewed as workplace learning - a 'part of the learning process about the nature of teacher work' (McNamara, Jones \& Murray 2015:8), 'a place in which the theory and practice divide may be overcome' (Flores 2015:246) and the setting for testing the validity of theories taught in coursework and for developing new theories through 
experiential learning (Korthagen 2011). The practicum allows student teachers to 'explore, practice, reflect, experiment, trial and demonstrate' (Hudson \& Hudson 2011:321) coursework concepts, and to use the knowledge and try out the different teaching strategies that they are exposed to in their coursework (Feiman-Nemser 2001). From a sociocultural perspective, the practicum is conceptualised by Hollins (2015:x) as 'guided practice within a professional community', implying that student teachers learn 'with and from peers, expert practitioners and the students they teach' (Hollins 2015:xi).

Despite the many purposes that are considered in the literature, Bacevich et al. (2015:203) caution that the 'purpose frequently goes unexamined or unstated when teacher preparation programs create requirements for clinical experience. Clarity about purpose is critical in designing appropriate opportunities for novices' learning about teaching'.

The most favourable setting for school experience is also debateable. Some argue for placing student teachers in innovative and highly functional schools (Whitford \& Metcalf-Turner 1999). Student teachers who were involved in teaching practice at well-functioning schools were more effective as teachers, even if they took up teaching positions in lower-functional schools (Ronfeldt \& Reiniger 2012). Others maintain that student teachers must have a range of school experiences. Placing student teachers only in middle class schools may not prepare them adequately for challenges that are prevalent in low socio-economic schools (Cherry 2015; White \& Forgasz 2016). Pennefather (cited in Robinson 2015:12) argues for placing student teachers in 'authentically diverse South African contexts'. In doing so, teacher education becomes more authentic. We agree that student teachers would benefit in the long run from exposure to a variety of schools, particularly if they encounter teachers who could serve as role models of how to deal with challenges in schools that are under-resourced or in impoverished communities - the situation in many schools in South Africa.

\section{Research methods}

We used a combination of quantitative and qualitative data to explore the student teachers' views of their practice learning experiences in the TS and at the WIL schools where they were involved in school experience.

We administered a questionnaire to the final-year student teachers $(n=100)$ enrolled in the Bachelor of Education in Foundation Phase Teaching. The questionnaire comprised questions with a Likert scale-type response. Students were asked to respond on a five-point scale, with $1=$ not at all, 2 = a bit/some, 3 = an average amount, $4=$ quite a lot and 5 = very much, to questions about how much they had learnt about specific teaching-related aspects through their involvement in the TS and WIL schools. The items included in the questionnaire not only related to aspects dealt with in the coursework methods courses, but also included aspects that are not typically dealt with in detail in the coursework, for example, classroom administration.

In addition, five focus group interviews were conducted, with 20 student teachers per group. Student teachers were asked to reflect on their learning experiences at the TS and WIL schools. The interviews allowed the student teachers to raise anything that they deemed important, but they were specifically prompted to talk about the nature of support and guidance they received from teachers. The interviews were audio-recorded.

Informed consent was obtained from the student teachers to use the data collected for research. They were notified of the purpose of the investigation, the procedures to be used to protect their anonymity and that their involvement was voluntary.

The responses to the questionnaire were analysed descriptively by counting the frequency of responses per item. To analyse the focus group interviews, we used the constant comparative method as adapted from Maykut and Morehouse (1994). We first obtained a holistic understanding of the interviews and noted the main ideas to be used as provisionally identified categories. Then we sorted identified units of meaning to the provisional categories, in the process of refining the categories, and also moving to higher levels of abstraction to eventually arrive at the themes that capture the prominent practice learning experiences of the student teachers - in WIL schools and in the TS. The credibility of the data analysis of the focus group interviews was addressed through testing of rival explanations. This implies that once categories were established, we purposefully looked for data not supporting the categories, thereby 'considering the weight of evidence' (Patton 1999:1191).

\section{Results}

The questionnaire results, showing the frequency of responses in relation to the items in the questionnaire, are presented in Table 1.

Figure 1 compares the views of student teachers $(n=100)$ on how much they learned at the TS and WIL schools, respectively, in relation to the questionnaire items.

Table 2 and Table 3 summarise the themes emanating from the analysed focus group data.

Table 2 and Table 3 pertain to the themes elicited from the focus group interviews in which student teachers were asked to reflect on their practice learning experiences at the WIL schools and the TS.

The questionnaire data show that, from the perspective of student teachers, practice learning in relation to the aspects dealt with in methods courses is indeed occurring 
TABLE 1: Frequency of responses: The views of student teachers $(n=100)$ on how much they learned in the teaching school and work integrated learning schools, respectively.

\begin{tabular}{|c|c|c|c|c|c|c|c|c|c|c|}
\hline \multirow[t]{2}{*}{ Item in questionnaire } & \multicolumn{2}{|c|}{ Not at all } & \multicolumn{2}{|c|}{ Some } & \multicolumn{2}{|c|}{ Average } & \multicolumn{2}{|c|}{ Quite a lot } & \multicolumn{2}{|c|}{ Very much } \\
\hline & TS & WIL & TS & WIL & TS & WIL & TS & WIL & TS & WIL \\
\hline How to teach so that learners are engaged & 1 & 10 & 9 & 2 & 20 & 46 & 55 & 30 & 15 & 12 \\
\hline Integrating technology in teaching & 0 & 60 & 5 & 20 & 25 & 10 & 50 & 11 & 20 & 9 \\
\hline How to create original resources for teaching & 3 & 10 & 5 & 10 & 20 & 22 & 32 & 30 & 50 & 28 \\
\hline Using a variety of methods in teaching & 5 & 2 & 10 & 17 & 20 & 25 & 23 & 24 & 42 & 32 \\
\hline How teachers should reflect on their lessons & 6 & 12 & 9 & 10 & 15 & 28 & 11 & 40 & 59 & 10 \\
\hline Managing learner behaviour in the classroom & 4 & 11 & 16 & 15 & 10 & 22 & 22 & 12 & 48 & 40 \\
\hline How teachers set classroom rules & 1 & 4 & 8 & 16 & 9 & 18 & 32 & 30 & 50 & 32 \\
\hline How to create a print-rich classroom & 0 & 11 & 2 & 21 & 18 & 25 & 22 & 20 & 58 & 23 \\
\hline How to use assessment to improve children's learning & 0 & 5 & 9 & 22 & 20 & 44 & 38 & 20 & 33 & 9 \\
\hline How to adapt lessons to address individual learner needs & 3 & 21 & 20 & 33 & 30 & 25 & 27 & 12 & 20 & 9 \\
\hline Choosing between different teaching methods for particular content & 8 & 17 & 10 & 20 & 13 & 20 & 25 & 22 & 44 & 21 \\
\hline How to manage classroom administration & 3 & 1 & 12 & 10 & 10 & 18 & 15 & 23 & 60 & 48 \\
\hline How to act as caring teachers & 7 & 5 & 10 & 17 & 19 & 20 & 23 & 28 & 41 & 30 \\
\hline
\end{tabular}

How to behave as a professional

TS, teaching school; WIL, work integrated learning.

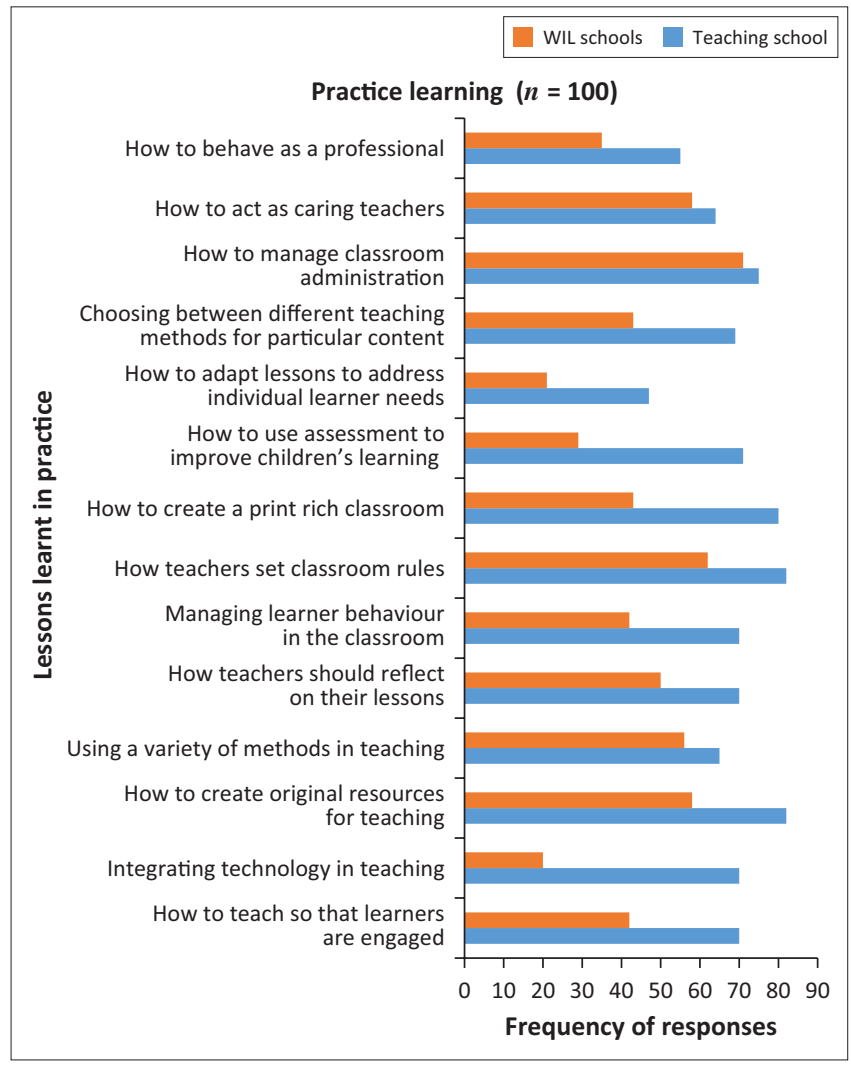

FIGURE 1: A comparison between the frequency of responses of outside schools versus the teaching school, including the quite a bit/quite a lot and very much responses only.

during their involvement in schools - at TS and WIL schools. They indicate that some learning is taking place with regard to all the aspects included in the questionnaire. The data show that student teachers are of the view that they learned more through their participation in the TS than at WIL schools. This is to be expected. The TS is a functional school and teachers at the school are fully aware that they should be acting as mentors to student teachers.

Figure 1 shows that the student teachers rated their practice learning experiences in the TS positively with regard to all
TABLE 2: Student teachers' views on their practice learning experiences at work integrated learning schools.

\begin{tabular}{|c|c|}
\hline Themes & Categories \\
\hline \multirow[t]{4}{*}{ Discouraging experience } & A lonely road \\
\hline & Felt clueless most of the time \\
\hline & Lack of resources \\
\hline & Lack of discipline in classrooms \\
\hline \multirow[t]{3}{*}{ Little support and mentoring } & Left on own \\
\hline & Expectation to take on full teaching responsibility \\
\hline & No or little role modelling \\
\hline Difference in theory and practice & $\begin{array}{l}\text { Coursework learning not reflected in experience } \\
\text { at the schools }\end{array}$ \\
\hline
\end{tabular}

the items. The student teachers rated their practice learning experiences in terms of how much they learned at WIL schools in general much lower than at the TS, with the exception of one item - how to manage classroom administration.

When the results emanating from the focus group interview data are taken into account, the picture becomes bleaker. Overall, with a few exceptions, student teachers experienced their involvement at the WIL schools as discouraging. In general, they received little support and mentoring from teachers at these schools. Furthermore, they indicated contradictions between their coursework learning and what they observed at the schools.

A major challenge highlighted in relation to WIL schools is absent teachers or teachers who use the student teachers to work for them:

The teacher took leave as soon as I got to school. I was given her class to look after. It was difficult. I could not discipline the kids and felt frustrated.

Many times I was left to look after the kids and was frustrated by the kids' noise.

Teacher enjoyed having me around, she spent a lot of time in the staffroom and left me alone with the kids.

I am given a lot of responsibility, the teacher says it's her time to relax and watch me. 
TABLE 3: Comparison between student teachers' views on their practice learning experiences at the teaching school and work integrated learning schools.

\begin{tabular}{|c|c|}
\hline Teaching school & WIL schools \\
\hline \multicolumn{2}{|c|}{ Theme: Teachers' involvement with lesson planning } \\
\hline $\begin{array}{l}\text { Teachers are helpful when it comes to } \\
\text { lesson planning and how to present } \\
\text { lessons. }\end{array}$ & $\begin{array}{l}\text { Teachers do not help with lesson } \\
\text { planning. They want students to } \\
\text { just take their lessons as is. }\end{array}$ \\
\hline $\begin{array}{l}\text { Teachers accommodate the university } \\
\text { lesson plan template even if it is long. }\end{array}$ & $\begin{array}{l}\text { The university lesson plan template } \\
\text { is seen as a waste of time and they } \\
\text { sometimes do not understand what } \\
\text { it requires, and thus choose not to } \\
\text { engage with it. }\end{array}$ \\
\hline $\begin{array}{l}\text { They understand that students still need } \\
\text { to learn and understand the lesson } \\
\text { components before they can use the } \\
\text { department's lesson template, which } \\
\text { is short and is meant for experienced } \\
\text { teachers. }\end{array}$ & $\begin{array}{l}\text { Teachers are impatient with students } \\
\text { and do not like explaining lesson plans } \\
\text { to students; instead, they prefer to just } \\
\text { sign the students' booklets without } \\
\text { questioning or understanding. }\end{array}$ \\
\hline \multicolumn{2}{|l|}{$\begin{array}{l}\text { Teachers are patient when explaining } \\
\text { the lesson plans to students. }\end{array}$} \\
\hline \multicolumn{2}{|c|}{ Theme: Teachers' handling of children and classroom management } \\
\hline $\begin{array}{l}\text { Teachers are always there in the } \\
\text { classrooms and assist with learner } \\
\text { discipline. }\end{array}$ & $\begin{array}{l}\text { Teachers leave classrooms and students } \\
\text { are frustrated and do not know how to } \\
\text { discipline learners. }\end{array}$ \\
\hline $\begin{array}{l}\text { They demonstrate different methods of } \\
\text { disciplining kids. }\end{array}$ & $\begin{array}{l}\text { Students feel lonely and lost when it } \\
\text { comes to how to handle and discipline } \\
\text { learners in the classrooms. }\end{array}$ \\
\hline \multicolumn{2}{|c|}{ Theme: The classroom as learning environment and teaching aids } \\
\hline $\begin{array}{l}\text { Classrooms are print rich and teachers } \\
\text { use the teaching aids when teaching. }\end{array}$ & $\begin{array}{l}\text { Some classrooms are print rich, but } \\
\text { resources on the walls are never used } \\
\text { by teachers and some teaching aids or } \\
\text { posters are not age appropriate. }\end{array}$ \\
\hline $\begin{array}{l}\text { They assist with the development of } \\
\text { teaching aids as per the lessons that } \\
\text { should be presented. }\end{array}$ & $\begin{array}{l}\text { They do not develop teaching aids for } \\
\text { individual lessons. Students have to } \\
\text { make teaching aids for the teachers. }\end{array}$ \\
\hline $\begin{array}{l}\text { Classrooms are spacious and } \\
\text { accommodate } 30 \text { learners, which } \\
\text { makes it easy for teachers to move } \\
\text { around and to attend to learners. }\end{array}$ & $\begin{array}{l}\text { Classrooms are small and overcrowded } \\
\text { with more than } 50 \text { learners. Teachers } \\
\text { cannot move around and thus do not } \\
\text { assist learners during class activities. }\end{array}$ \\
\hline \multicolumn{2}{|l|}{ Theme: Teachers' mentoring role } \\
\hline $\begin{array}{l}\text { Teachers understand their role as } \\
\text { mentors, which is to guide, support and } \\
\text { have good relationships with students } \\
\text { and always be willing to give a helping } \\
\text { hand. }\end{array}$ & $\begin{array}{l}\text { Teachers do not view themselves as } \\
\text { mentors to students; they see } \\
\text { students as relievers from their duties } \\
\text { and thus spend time in the staffroom } \\
\text { rather than being with the student in } \\
\text { the classroom. }\end{array}$ \\
\hline \multicolumn{2}{|c|}{ Theme: Congruence between coursework learning and practice learning } \\
\hline $\begin{array}{l}\text { Students enjoy being teaching assistants } \\
\text { as they get to learn and experience } \\
\text { many things that are taught at } \\
\text { university. }\end{array}$ & $\begin{array}{l}\text { Students do not see any link between } \\
\text { what they learn from university with } \\
\text { what they see in classrooms. }\end{array}$ \\
\hline
\end{tabular}

WIL, work integrated learning.

Student teachers indicated that little or no mentoring took place at WIL schools, as the following excerpts from the interviews attest:

Very little assistance is given to me concerning lesson planning, discipline and other classroom matters.

The teacher was good to me but insisted I just copy her lessons. I got no support or guidance on how to plan lessons.

The teacher could not understand my lesson plan and insisted I just take her lessons and copy them.

I don't like to go to the schools. Unlike XXX (the teaching school) teachers, these teachers don't like us, they give us a lot of work without explaining anything. (Student teacher, WIL school, n.d.)

Student teachers also experienced practices that are incongruent with what they learn in coursework at the WIL schools, particularly in relation to how to deal with school learners:

Learners were divided according to their abilities. Teacher focused on the clever kids only. (Student teacher, WIL school, n.d.)
The teachers do not pay attention to learners with learning barriers. They only work with the brilliant ones. Teachers' [sic] still use corporal punishment. Even though we were taught not to use it. (Student teacher, WIL school, n.d.)

Student teachers commented on the school environment of WIL schools, which was not conducive to learning:

The problem was that in the classroom there were two classes, learners from two classes and two teachers. The class was kind of over filled with 58 learners. (Student teacher, WIL school, n.d.)

The classroom was very empty, no teaching aids. Teacher says its time consuming to make them and she does not have money to buy. (Student teacher, WIL school, n.d.)

Even though negative observations dominate the student teachers' views on their learning experiences at WIL schools, positive experiences were also recounted, as shown in the following example:

The teacher is very welcoming and friendly and she has been teaching grade one for more than two decades and she has a lot of knowledge and she taught me discipline strategies, reading strategies and other important information. She guided me on how to do other things in class with the children. (Student teacher, WIL school, n.d.)

The student teachers reported on productive learning experiences at the TS. This included positive role modelling, assistance with lesson planning and helpful mentoring relationship with the teachers. They noted, for example:

The teacher helped me to prepare my lesson plans and showed me the themes and topics to use. She showed me all the teaching aids that they used during lessons and the workbooks both for classwork and homework. (Student teacher,TS, n.d.)

We plan with the teachers and they are of great help as they guide us on how to present the lessons and what teaching aids to prepare. (Student teacher, TS, n.d.)

The teacher was friendly. She made it easy for me in all times. She is a good mentor, good guiding skills and calm. The teacher was very supportive. (Student teacher, TS, n.d.)

The teacher showed some good qualities that a teacher should possess always. The teacher was always supportive to the learners and acted as guidance regularly. (Student teacher, TS, n.d.)

She told me just to be myself during my presentations, and showed me how to react when encountering disturbing issues like when there is chaos in the class. (Student teacher, TS, n.d.)

It was mentioned that some positive changes had occurred at the TS. The teachers at the school had not always been as welcoming. Thus, the development efforts at the school have paid dividends:

Teachers at the teaching school are welcoming now. In the previous years they did not want us in the classrooms and did not engage us in the lessons. They taught and we were left sitting there, without communicating with us, nor allowing us to do anything in their classroosms. (Student teacher, TS, n.d.)

\section{Ethical considerations}

The research-related work in this school had overall ethical clearance in a similar way as the teaching school 
(Funda UJabule School) at the University of Johannesburg Soweto Campus.

This study was carried out in accordance with the guidelines as set out by the University of Johannesburg, Faculty of Education Ethics committee and guidelines of governing body overseeing research in the teaching school. All participants gave written informed consent in accordance with the Declaration of Helsinki.

\section{Student teachers' practice learning experiences: Fruitful and troubled}

The overall pattern in the data shows that the student teachers are of the view that the practice learning experiences were fruitful - more so not only at the TS, but also at the WIL schools, despite difficulties experienced at these schools. It is of course difficult to ascertain whether or not the practicum in WIL schools reinforced patterns of behaviour, which may perpetuate the undesirable habits and practices present at low-performing schools. The workplace learning risk that Korthagen (2016:358) identifies is pertinent here. He warns that practical experience does not equal professional development. In fact, it can easily become a process of 'socialization into established patterns'.

The results also show the dilemmas that are prevalent with regard to the school experience component of initial teacher education programmes in South Africa. This is even more so in the rural areas.

We concur that student teachers should be involved in schools where they would experience some correspondence between coursework learning and the approach of the school where good practice is modelled (Banks et al. 2005; Darling-Hammond \& Baratz-Snowden 2005). We also agree that coherent teacher education relies on the collaboration of the 'triad' (Bacevich et al. 2015:203) - student teacher, the supervising teacher at the school and the teacher educators.

However, this remains an elusive ideal at the majority of teacher education institutions (TEIs) in South Africa. At this university, all the students live in residences on the university campus. The number of schools that are within travelling distance of the residences is not sufficient to accommodate the student teachers. Furthermore, the student teachers must have the opportunity to teach in one of the two African languages offered by the university. One of the languages is not used in schools in the area surrounding the university. In addition, the vast majority of the student teachers come from impoverished backgrounds. Thus, they do not have sufficient financial means to travel long distances to schools. Despite being not ideal, the only reasonable way to deal with this is that student teachers are involved in school experience close to their homes. This would enable them to stay at home for the duration of the school experience. Many of these schools are low-functional. Another issue is that, because of the long distances and the wide spread of placements, the small group of teacher educators are not able to visit a student teacher more than once at the schools. Consequently, developing a collaborative relationship with the teachers who host student teachers at these schools is tricky. The research of Robinson (2015) indicates that the school experience issues at this university are not unique. Other TEIs in South Africa have similar predicaments and many concede that their arrangements for school experience and collaboration with the WIL schools are not optimal because of resource constraints.

Another dilemma is that teachers who are supposed to serve as mentors for student teachers are often not taking up this role. The data point to this. Some show no interest - they leave the student teachers alone with the children - while others do not provide any guidance. The research conducted by Marais and Meier (2004) with 165 third-year student teachers at a South African university also identifies inadequate mentoring as an issue. If mentoring is lacking, the result is that work becomes subordinate to learning - 'work rather than learning' becomes the 'leading activity' (Conway, Murphy \& Rutherford 2014:221) during school experience. Student teachers are given limited or no opportunity for 'peripheral participation' (Lave \& Wenger 1991) because they must take 'full responsibility roles prematurely' (Conway et al. 2014:230).

One can only speculate about the reasons for this teacher behaviour. However, research on school experience in the South African context reveals that what the student teachers describe in this study is not unique. The school experience component of teacher education programmes is often afflicted by difficulties (Mukeredzi \& Mandrona 2013). Challenges include lack of time and space to mentor student teachers because of heavy teaching loads and overcrowded classrooms (Robinson 2015). Other studies note that teachers are unwilling or reluctant to mentor student teachers (Mutemeri \& Chetty 2011; Odendaal 2015) and student teachers report on teachers 'disappearing' (Kiggundu \& Nayimuli 2009).

The quantitative and qualitative data reveal supportive practice learning experiences in the TS. The questionnaire did not touch on the role of the mentor teachers in producing the learning. This can be inferred from the focus group interview data. Student teachers point to the personal attributes of teachers - calm, friendly and supportive. Furthermore, the data signal that the teachers are beginning to view themselves as 'teacher educators willing to plan for the learning of a novice' (Feiman-Nemser \& Buchman 1985:64). This is encouraging particularly because the teachers at the school were not specifically selected for the role of teaching schoolteachers - they are 'ordinary' teachers employed in the school.

In describing their experiences in the TS, student teachers noted the guidance role of the teachers, especially in terms of lesson planning and presentation. Modelling of good practice, aligned with coursework, is also mentioned, particularly in relation to classroom discipline and working with children 
with differing abilities. Thus, the teachers are delivering on the tasks assigned to them as mentor teachers. However, the data signal that teachers are not moving beyond providing support and giving practical advice on the presentation of lessons and classroom management skills, as important as these are. Mentoring needs to guide student teachers towards pedagogical decision-making within the complexity of the classroom (Ramsaroop 2016). School experience is the ideal space to foreground the 'unpredictability and messiness inherent in practice' (Grossman et al. 2009:2061). This implies inter alia that mentor teachers need to 'inquire into reasons for actions' rather than telling student teachers how to perform (Smith \& Ulvick 2014:268).

So - what is to be done? We are of the view that despite the challenging environment that the WIL schools presented and the incongruence between coursework and school experiences that student teachers encountered, school experience in these schools potentially enables an understanding of the challenges that are typical in many South African schools. Thus, we argue for placing students in a variety of schools, even lowfunctional schools. An important point here is that student teachers must be prepared thoroughly for the circumstances that they may encounter, even though some were probably educated in similar schools. As students of teaching they must be assisted to move beyond and challenge the 'apprenticeship of observation' (Lortie 1975). For this, they need 'lenses for seeing and making sense of practice' (Cochran-Smith \& Lytle 1999:292) that will help them to actively seek practice learning opportunities and to avoid a deficit attitude towards the school experience. They must be prepared to look intentionally for what the teachers in the WIL schools 'do have to offer' (instead of what they do not offer), even if the teachers' teaching practices 'do not align to the ideal of ambitious practice' (Horn \& Campbell 2015:154).

Thorough debriefing after returning from school experience could become a productive practice learning experience through eliciting 'student concerns' (Kessels \& Korthagen 2001) as 'generative themes' (Shor 1992) to invoke discussion and reflection. Student teachers should be allowed to express their frustrations, but practice learning should be foregrounded. Student teachers could be requested to comment, in turn, on at least one important learning during school experience and how this has influenced their vision of teaching (Beck \& Kosnik 2017). Debriefing conversations also provide the space to reinforce the relevance of coursework for the challenges that student teachers encountered. Kessels and Korthagen (2001) explain how guided reflection on student teachers' concrete experiences and 'concerns' could generate powerful learning. The guided reflection helps to structure the experiences and concerns for student teachers through, for example, 'clarification, classification, extracting core ideas and principles inherent to the experience and making tentative generalizations through extrapolation' (Gravett \& Ramsaroop 2017:7). Such guided reflection conversations make for fertile ground to fruitfully (re) introduce pertinent ideas from the coursework.
However, we maintain that student teachers must preferably be exposed to good practice before encountering challenging practice. Once student teachers have experienced a highfunctioning school and modelling of exemplary teaching practices, combined with mentoring by expert teachers, they will be in a much better position to deal with the challenges in low-functional schools (Ramsaroop 2016). The student teachers at this university encountered the dailyness of teacher work in a functional school. Also, there was some modelling of good practice and some mentoring. Were it not for the TS, the majority of the student teachers would not have been exposed to practice that has some congruence with coursework learning and teachers who model such practice. It potentially also implies that student teachers within the same programme may have vastly different practicum experiences, resulting in unequal opportunities to learn the practice of teaching (Bacevich et al. 2015:203).

We are of the view that a TS holds much promise for serving as an intentionally designed 'learning place' (Conway et al. 2014) for educating student teachers. To us this is a place where 'intentional investigation of practice' (Cochran-Smith \& Lytle 1999:250) can take place and where 'cognitive apprenticeship' (Collins, Brown \& Holum 1991) learning can be foregrounded. Apprenticeship learning in teacher education would involve that the mentor teacher uses modelling, scaffolding, fading and coaching to guide student teachers. However, we argue that these actions are inadequate on their own. Teaching is complex. Therefore, it is not beneficial to student teachers to emulate the behaviour or actions of mentor teachers unless the student teachers gain access to the reasoning that underlies the expert teachers' actions. Mentor teachers must make their thinking explicit to student teachers (Gravett \& Ramsaroop 2017).

Our study, although involving only one TEI, suggests that a TS as a teacher education site holds the promise to strengthen initial teacher education considerably. DarlingHammond et al. (2017) note that in virtually all of the countries with high-performing school systems, schooluniversity partnerships are developed or strengthened to provide clinical experience for connecting theory and practice. Finnish teacher education is widely acknowledged as a world leader in teacher education (Darling-Hammond et al. 2017). In Finland, the bulk of practice teaching takes place at university-affiliated schools. These schools work very closely with the university and are integral to the initial teacher education system in Finland. During their practice teaching, student teachers observe lessons taught by expert teachers and they teach under the guidance of the supervising teachers (Sahlberg 2010). Also, within the South African context, encouraging results are reported (Gravett \& Ramsaroop 2017; Loukomies, Petersen \& Lavonen 2018) in relation to the potential of TSs for bolstering student teacher learning for the teaching profession (Ramsaroop 2016), despite challenges (Gravett, Petersen \& Petker 2014).

However, we argue that if the full affordances of TSs are to be developed, investment in these schools is required. 
This investment needs to focus particularly on the leadership of and teachers at the school. Commitment of the school leadership towards developing the school into an environment where student teachers will experience exemplary practice is crucial, coupled with the development of the teachers to strengthen their practice towards becoming 'expert teachers'. Student teachers need the guidance of expert teachers as mentors who can demonstrate how to organise 'productive learning activities and respond to both predictable and unexpected problems that arise in classrooms' (LePage et al. 2005:353). There are similarities between experienced teachers and expert teachers, but expert teachers have a multidimensional perspective of the classroom; they integrate a range of skills, strategies and routines to make appropriate judgements in the classroom and they perform 'at a significantly higher level than what is gained through experience in itself' (Smith \& Ulvik 2014:269).

Furthermore, focused mentor development is required. A good (and even expert) teacher does not automatically become a good mentor teacher, and the skills needed for mentoring do not 'naturally grow out of accumulated teaching experience' (Smith \& Ulvik 2014:268). Feiman-Nemser and Buchman (1985) rightly make the point that:

If classrooms are to become settings for learning to teach that go beyond adaptation and unreflective imitation, purposes of learning to teach cannot automatically be subordinated to the goal of pupil learning. Teachers also must see themselves as teacher educators willing to plan for the learning of a novice. (p. 64)

They also maintain that becoming a teacher educator implies that the teacher must shift into another role. A teacher's experience as teacher alone is not sufficient. Teachers must be prepared for their roles as mentor teachers (Smith \& Ulvik 2014).

\section{Conclusion}

In this article, we reported on the practice learning experiences of a group of final-year student teachers. We found that student teachers are of the view that through their involvement in WIL schools and the TS they learned about a variety of aspects related to teaching practice. Thus, school involvement fosters practice learning, despite difficulties encountered in WIL schools. Furthermore, student teachers reported on significant learning gains in the TS.

We made the case that student teachers could benefit from school experience even when the circumstances are less than favourable. However, they need to be prepared well to enable them to see these schools as sites of learning. In addition, reflection guided by post-school experience, coupled with input from teacher educators, drawing on coursework ideas, is essential. Furthermore, we are of the view that the notion of TSs suggested in the Framework (DBE \& DHET 2011) indeed has the potential to strengthen the teaching practice or school experience component of teacher education programmes through enabling meaningful WIL. International experience with school partnerships and the experience with a TS at another South African university also attest to this.

\section{Acknowledgements}

The support from funders, USAID and Elma Foundation, to support the development of the teaching school is gratefully acknowledged.

\section{Competing interests}

The authors declare that they have no financial or personal relationships that may have inappropriately influenced them in writing this article.

\section{Authors' contributions}

L.J. was responsible for data collection and analysis and input into the writing. S.J.G. was responsible for guiding the research design, literature review and writing up of the article.

\section{Funding information}

The development work in the teaching school was supported mainly by a USAID and Elma Foundation grant.

\section{Data availability statement}

Data sharing is not applicable to this article as no new data were created or analysed in this study.

\section{Disclaimer}

The views and opinions expressed in this article are those of the authors and do not necessarily reflect the official policy or position of any affiliated agency of the authors.

\section{References}

Abdal-Haqq, I.C., 1997, Resources on professional development schools. An annotated bibliography and resource guide, 2nd edn., AACTE, New York, NY.

Bacevich, A., Dodman, S.L., Hall L.L. \& Ludwig, M., 2015, 'Building a research agenda and developing solutions for challenges in clinical experiences', in E.R. Hollins (ed.), Rethinking field experiences in preservice teacher preparation: Meeting new challenges for accountability, pp. 202-221, Taylor \& Francis, New York, NY.

Banks, J., Cochran-Smith, M., Moll, L., Richert, A., Zeichner, K., LePage, P. et al., 2005, 'Teaching diverse learners', in L. Darling-Hammond \& J. Bransford (eds.), Preparing teachers for a changing world. What teachers should learn and be able to do, pp. 232-274, Jossey-Bass, San Francisco, CA.

Beck, C.V. \& Kosnik, C., 2017, 'The continuum of pre-service and in-service teacher education', in D.J. Clandinin \& H. Hussu (eds.), The Sage handbook of research on teacher education, pp. 107-122, Sage, London.

Burn, K., Childs, A. \& McNicholl, J., 2007, 'The potential and challenges for student teachers' learning of subject specific pedagogical knowledge within secondary school subject departments', The Curriculum Journal 18(4), 429-446. https://doi. org/10.1080/09585170701687886

Cherry, J., 2015, 'Diversity education, practicum experience for preservice teachers', American International Journal of Social Science 4(6), 9-17.

Cochran-Smith, M. \& Lytle, S.L., 1999, 'Relationships of knowledge and practice: Teacher learning in communities', Review of Research in Education 24, 249-305. https://doi.org/10.2307/1167272

Collins, A., Brown, J.S. \& Holum, A., 1991, 'Cognitive apprenticeship: Making thinking visible', American Educator 15(3), 6-11.

Conway, P.F., Murphy, R. \& Rutherford, V., 2014, 'Learningplace' practices and preservice teacher education in Ireland: Knowledge generation, partnerships and pedagogy', in O. McNamara, J. Murray \& M. Jones (eds.), Workplace learning in pedagogy', in O. McNamara, J. Murray \& M. Jones (eds.), Workplace learning in
teacher education: International practice and policy: 10 (Professional learning and development in schools and higher education), pp. 221-243, Springer, Heidelberg. 
Darling-Hammond, L., 2006, Powerful teacher education: Lessons from exemplary programs, John Wiley \& Sons, Hoboken, NJ.

Darling-Hammond, L. \& Baratz-Snowden, J. (eds.), 2005, A good teacher in every classroom: Preparing the highly qualified teachers our children deserve, John Wiley \& Sons, San Francisco, CA.

Darling-Hammond, L., Burns, D., Campbell, C., Goodwin, A.L., Hammerness, K., Low, E. et al., 2017, Empowered educators: How high-performing systems shape teaching quality around the world, Wiley, San Francisco, CA.

Department of Basic Education and Department of Higher Education and Training (DBE \& DHET), 2011, Integrated strategic planning framework for teacher education and development in South Africa, Government Printer, Pretoria.

Department of Higher Education and Training (DHET), 2015, Revised policy on the minimum requirements for teacher education qualifications, National Qualifications Framework Act 67 (2008), Government Gazette, vol. 38487, no. 596, Government Printer, Pretoria.

Feiman-Nemser, S., 2001, 'From preparation to practice: Designing a continuum to strengthen and sustain teaching', Teachers College Record 103(6), 1013-1055. https://doi.org/10.1111/0161-4681.00141

Feiman-Nemser, S. \& Buchman, M., 1985, 'Pitfalls of experience in teacher preparation', Teachers College Record 87(1), 53-65.

Flores, M.A., 2015, 'Teacher learning in the workplace in pre-service teacher education in Portugal: Potential and limits from a pre-service teacher perspective', in O. McNamara, J. Murray \& M. Jones (eds.), Workplace earning in teacher education: International practice and policy: 10 (Professional learning and development in schools and higher education), pp. 243-261, Springer, Netherlands.

Gravett, S., Petersen, N. \& Petker, G., 2014, 'Integrating foundation phase teacher education with a 'teaching school' at the University of Johannesburg', Education as Change 18(suppl. 1), S107-S119. https://doi.org/10.1080/16823206.2013.877357

Gravett, S. \& Ramsaroop, S., 2017, 'Teaching schools as teacher education laboratories', South African Journal of Childhood Education 7(1), a527. https://doi.org/10.4102/ sajce.v7i1.527

Grossman, P., Compton, C., Igra, D, Ronfeldt, M, Sharan, E. \& Williamson, P.W., 2009, 'Teaching practice: A cross-professional perspective', Teachers College Record 111(9), 2055-2100.

Hollins, E.R., 2015, Rethinking field experiences in preservice teacher preparation Meeting new challenges for accountability, Taylor \& Francis, New York, NY.

Horn, I.S. \& Campbell, S.S., 2015, 'Developing pedagogical judgment in novice teachers: Mediated field experience as a pedagogy for teacher education', Pedagogies: An
International Journal 10(2), 149-176. https://doi.org/10.1080/1554480X.2015. Internationa
1021350

Hudson, P. \& Hudson, S., 2011, 'Converting theory to practice: University-school collaboration on devising strategies for mentoring pedagogical knowledge', International Journal of Learning 18(2), 319-329.

Kiggundu, E. \& Nayimuli, S., 2009, 'Teaching practice: A make or break phase for student teachers', South African Journal of Education 29, 345-358.

Kessels, J. \& Korthagen, F.A.J., 2001, 'The relation between theory and practice: Back to the classics', in F.A.J. Korthagen (ed.), Linking practice and theory. The pedagogy of realistic teacher education, pp. 20-31, Lawrence Erlbaum, Mahwah, NJ.

Korthagen, F.A.J., 2011, 'Making teacher education relevant for practice: The pedagogy of realistic teacher education', Orbis Scholae 5(2), 31-50. https://doi. org/10.14712/23363177.2018.99

Korthagen, F.A.J., 2016, 'Pedagogy of teacher education', in J. Loughran \& M.L. Hamilton (eds.), International handbook of teacher education, pp. 331-336, Springer, Singapore.

Lave, J. \& Wenger, E., 1991, Situated learning: Legitimate peripheral participation, Cambridge University Press, New York, NY.
LePage, P., Darling-Hammond, L., Akar, H., Gutierrez, C., Jenkins-Gunn, E. \& Rosebrock K. 2005, 'Classroom management', in L.'Darling-Hammond \& J. Bransford (eds.), Preparing teachers for a changing world. What teachers should learn and be able to do, pp. 327-357, Jossey-Bass, San Francisco, CA.

Lortie, D., 1975, Schoolteacher, University of Chicago Press, Chicago, IL.

Loukomies, A., Petersen, N. \& Lavonen, J., 2018, 'A Finnish model of teacher education informs a South African one: A teaching school as a pedagogical laboratory', South African Journal of Childhood Education 8(1), a593. https://doi.org/10.4102/ sajce.v8i1.593

Marais, P. \& Meier, C., 2004, 'Hear our voices: Student teachers' experiences during practical teaching', Africa Education Review 1(2), 220-233. https://doi.org/ $10.1080 / 18146620408566281$

Maykut, P. \& Morehouse, R., 1994, Beginning qualitative research. A philosophical and practical guide, The Falmer Press, London.

McNamara, O., Jones, M. \& Murray, J., 2015, 'Framing workplace learning', in O. McNamara, J. Murray \& M. Jones (eds.), Workplace learning in teacher education: International practice and policy: 10 (Professional learning and development in schools and higher education), pp. 1-28, Springer, Heidelberg.

Mukeredzi, T.G. \& Mondrona, A.R., 2013, 'The journey to become professionals: Student teachers' experiences of teaching practice in a rural South African context', International Journal of Educational Research 62, 141-151. https://doi. org/10.1016/j.ijer.2013.07.010

Mutemeri, J. \& Chetty, R., 2011, 'An examination of university-school partnerships in South Africa', South African Journal of Education 31, 505-517. https://doi.org/ 10.15700/saje.v31n4a325

Odendaal, R, 2015, 'What is the potential role of case-based teaching to enhance student teachers' development as prospective teachers?', Master's dissertation, Faculty of Education, University of Johannesburg.

Patton, M.Q., 1999, 'Enhancing the quality and credibility of qualitative analysis', Health Services Research 34(5), 1189-1208.

Ramsaroop, S., 2016, 'The potential of teaching schools in South Africa to enable learning for the teaching profession', PhD thesis, Faculty of Education, University of Johannesburg, Johannesburg.

Robinson, M., 2015, Teaching and learning together: The establishment of professiona practice schools in South Africa. A research report for the Department of Higher Education and Training, Stellenbosch University, Stellenbosch.

Ronfeldt, M. \& Reinger, M., 2012, 'More or better student teaching?', Teaching and Teacher Education 28, 1091-1106.

Shor, I., 1992, Empowering education. Critical teaching for social change, The University of Chicago Press, Chicago, IL.

Sahlberg, P., 2010, 'The secret of Finland's success: Educating teachers', Research brief, Stanford Center for Opportunity Policy in Education, Stanford University, Palo Alto, CA

Smith, K. \& Ulvik, M., 2014, 'Learning to teach in Norway: A shared responsibility', in O. McNamara, J. Murray \& M. Jones (eds.), Workplace learning in teacher education: International practice and policy: 10 (Professional learning and development in schools and higher education), Kindle edn., pp. 262-278, Springer, Heidelberg.

White, S. \& Forgasz, R., 2016, 'The practicum: The place of experience?', in J. Loughran \& M.L. Hamilton (eds.), International handbook of teacher education, pp. 231-266, Springer, Singapore.

Whitford, B.L. \& Metcalf-Turner, P., 1999, 'Of promises and unresolved puzzles: Reforming teacher education with professional development schools', in G. Griffin (ed.), The education of teachers: 98th NSSE Yearbook of the National Society for the Study of Education, pp. 257-278, National Society for the Study of Education, n.p. 